\title{
Evaluation of Some Technological Treatments on Juice Quality of Both Sugar Cane and Sweet Sorghum as Fresh Bever or Raw Material for Syrup (Black Honey) Production
}

\author{
Rokaia Ramadan Abdelsalam ${ }^{1}$, Waled Mohamed Abdel-Aleem ${ }^{2}$, Hussein Ferweez ${ }^{3}$ \\ ${ }^{1}$ Food Science Department, Faculty of Agriculture, Minia University, El Minia, Egypt \\ ${ }^{2}$ Central Laboratory of Organic Agriculture, Agriculture Research Center, El Minia, Egypt \\ ${ }^{3}$ Food Science and Technology Department, Faculty of Agriculture, New Valley University, El Kharga, Egypt
}

Email address:

ferweez10@nv.aun.edu.eg (H. Ferweez)

\section{To cite this article:}

Rokaia Ramadan Abdelsalam, Waled Mohamed Abdel-Aleem, Hussein Ferweez. Evaluation of Some Technological Treatments on Juice Quality of Both Sugar Cane and Sweet Sorghum as Fresh Bever or Raw Material for Syrup (Black Honey) Production. International Journal of Nutrition and Food Sciences. Vol. 9, No. 4, 2020, pp. 95-103. doi: 10.11648/j.ijnfs.20200904.11

Received: May 8, 2020; Accepted: May 27, 2020; Published: July 17, 2020

\begin{abstract}
The juice of either sugarcane (CJ) or sweet sorghum (SJ) is used as a raw material for the production of syrup (black honey).So far, no quality standards are reported for sugarcane juice or sweet sorghum as a fresh drink or raw material for the production of syrup. Therefore, this research was designed to study the quality of juice for each of them by replacing the sugarcane juice with sweet sorghum juice in proportions $(25,50$ and $75 \%)$. The physic-chemical properties represented in TSS, $\mathrm{pH}$, percentage of purity as their highest values in sugarcane juice (A1) and the lowest values for them in sweet sorghum juice (A5), while the highest degree of color unit was recorded in sweet sorghum juice (A5) and the lowest value for color unit in sugarcane juice (A1). Significant differences were found in the physical, chemical and sensory properties as a result of the different treatments with increase of replacement percentage. The reducing sugars, acidity, protein and color values were increased, while the decrement were found in TSS, percentage of purity, total sugars, fats, ash, and minerals (potassiumsodium-calcium-magnesium-iron). Citric acid (B3) treatment resulted in obtaining a light-colored juice with a higher content of reducing sugars compared with the other treatments, and the pre-heating (B2) to $80 \pm 0.5^{\circ} \mathrm{C}$ was improved the sensory properties and general acceptance. It could be concluded that the replacing rate of $25 \%$ (A2) with the pre-heating (B2) recorded the best sensory properties and is recommended for the production of canned juice or could be used as a raw material for the production of honey with a subsequent study of its production as a natural energy drink characterized for its long preservation period.
\end{abstract}

Keywords: Cane Juice, Sorghum Juice, Formula, Clarification Treatment

\section{Introduction}

Juice of sugar cane is used as fresh bever or raw material for syrup (black honey) production. Black honey is separated in two phases, one of them is constituted by crystallized sucrose and the other one is constituted by liquid sucrose rich in sugars Sugar cane juice is highly nutritious, containing natural sugars, several minerals, vitamins, amino acids, organic acids, starch, phosphatides, and gums. Sugar cane juice cannot be stored normally for more than $6 \mathrm{~h}$ and commercially it has short shelf life. The shelf life of fresh sugarcane juice is quite limited due to the high rates of microbiological and enzymatic reactions which take place after extraction. Sorghum juice taste was found to be sour, probably due to aconitic acid level. Sorghum juice contains 13 to $17 \%$ sugar, of which 10 to $14 \%$ is sucrose. Sweet sorghum (Sorghum bicolor L. Moench) juice, used as an alternate to sugar cane juice in treacle or black honey production $[6,8,14,23]$.

There are no quality standards for juice of sweet sorghum or sugar cane as raw material for syrup production. The lack of quality, harmlessness are some problems, which have been generated. The juice quality is directly related to the sucrose concentration and the purity of the raw material, the sugarcane juice, extracted from the contains about $75-82 \%$ of water and 18 - 
$25 \%$ of soluble solids. The soluble solids are grouped into sugars - sucrose, glucose and fructose, with the respective ratios: 14.5 $23.5,0.2-1.0$ and $0.0-0.5 \%$, in addition to the organic $(0,8-1.5 \%)$ and inorganic (0.2-0.7\%) no-sugars. When the concentration (brix) and the $\mathrm{pH}$ increase in the juice, the crystallization in black honey or cane syrup is evident, due to an incorrect inversion of sucrose. Sorghum syrup taste was found to be very sour, probably due to high aconitic acid levels. Information about juice composition is necessary for the evaluation of the syrup quality, besides allowing and improving the development and application of dietary guidelines in the public health nutrition field $[13,17,18,19,21$, 22].

This investigation presents pioneering developmental work on juice both of sugar cane and sweet sorghum. Therefore, the purpose of this study was to determine physiochemical properties and sensory evaluation of juice extracted from sugar cane and sweet sorghum as fresh bever or raw material for syrup (black honey) production as a result of some technological treatments such as formula of juice extracted from both of sugar cane and sweet sorghum as well as clarification treatments of juice. Thus, finding an economical and suitable formula and clarification treatment of juice as fresh bever or raw material for syrup (black honey) production.

\section{Materials and Methods}

This work was carried out at laboratories of Food Sci. and Tenhno. Departments of Fac. Agric., New Valley Univ. and El. Minia Univ. as well as Mallawi Agri. Res. El. Minia, Egypt at 2017 season. A split plot design with four replications was used. The main plots were assigned to formula from cane juice (CJ) and sorghum juice (SJ) as follow:

1. A1: $100 \%$ cane juice (CJ).

2. A2: $75 \%$ cane juice: $25 \%$ sorghum juice.

3. A3: $50 \%$ cane juice: $50 \%$ sorghum juice.

4. A4: $25 \%$ cane juice: $75 \%$ sorghum juice.

5. A5: $100 \%$ sorghum juice (SJ).

The clarification treatments of juice $\left(\mathrm{B}_{1}=\right.$ untreated, control, $\mathrm{B}_{2}=$ pre-heating of juice, $80 \pm 0.50^{\circ} \mathrm{C}$ for 10 minutes, and $\mathrm{B}_{3}=$ $0.05 \%$ citric acid) were randomly distributed in sub plots.

\subsection{Materials}

Sugar cane (Saccharum officinarum L.) cultivar, namely "Giza Taiwan 9-54 and known among growers as C9. Sweet sorghum (Sorghum bicolor L. Moench) cultivar, namely "Honey". Samples of sugarcane or sweet sorghum juice, obtained by crushing cleaned and peeled sugarcane or sweet sorghum stems, and harvested in El. Minia Governorate at age 110 and 365 days for sweet sorghum and sugar cane, respectively.

\subsection{Juice Extraction}

At physiological maturity of the crop, uniform and health stalks from central four rows of each plot were sampled for juice extraction and subsequent sugar analysis. Juice extraction of sugar cane or sweet sorghum was done from all three crushing treatments as per the experimental design described above. In all treatments, the stalk juice was extracted with a power operated three-roller sugarcane machine miller without imbibition water and was weighed immediately. The samples of extracted juice was filtered immediately with standard Whatman filter paper to remove large solids. Formula of juice from sugar cane or sweet sorghum and juice clarification treatments were conducted as previously mentioned.

\subsection{Physical and Chemical Analysis}

Fresh juice of sugar cane, sweet sorghum, different formula or clarification treatments was transferred to standard glass flasks and was analyzed for physichemical properties as follow:

Total soluble solids\% (TSS\%) was determined using a digital hand-held refractometer. Sucrose content (Pol per cent) was directly measured using polarimeter using lead acetate clarification. The $\mathrm{pH}$ value was determined with a $\mathrm{pH}$-meter. The moisture was performed gravimetrically by direct drying in an oven at $105^{\circ} \mathrm{C}$. The concentration of reducing sugars (RS) was determined according to LaneEynon's methodology using as a standard a 5\% glucose solution. Crude protein was determined by the Kjeldal method $(\mathrm{N} \times$ 6.25). The ash content was obtained by gravimetry, through sample dehydration and subsequent furnace burning ash and total lipids were determined by Soxhlet method according to standard method. The titratable acidity of juice was determined by the sample titration with $0.01 \mathrm{M}$ standardized sodium hydroxide $(\mathrm{NaOH})$ solution until observation of the visual endpoint. These properties of juice were determined as described in [2]. Color of juice (brown pigment formation) was determined measuring the absorbance of diluted samples at $420 \mathrm{~nm}$ as as ICUMSA units $[12,25]$. Purity is sucrose present in the total solids content in the juice, and it was computed with the formula i.e., purity $\%=$ Sucrose $\%$ x 100/Juice Brix accoding to [22].

Mineral composition:

Analyzing the minerals, i.e. $\mathrm{K}$ and $\mathrm{Na}(\mathrm{mg} / 100 \mathrm{~g} \mathrm{DWB})$ of juice samples were determined by "Carlzeiss flame photometer. $\mathrm{Ca}, \mathrm{Mg}(\mathrm{mg} / 100 \mathrm{~g} \mathrm{DWB})$ and $\mathrm{Fe}$ (ppm) were determined using Perkin Elmer atomic. The samples of juice were prepared and determined by the methods described in $[2,12]$.

\subsection{Sensory Evaluation}

Sensory evaluation for the studied juice samples were carried out according to [21]. Judges consisted of 18 staff were evaluated the four sensory characteristics, i.e. taste, consistency, flavor and preference. the judge scoring evaluation was 25 points for each character.

\subsection{Statistical Analysis}

The data were analyzed according to the Fisher's method of analysis of variance (ANOVA) according to procedure out lined by [9]. Least significant difference (LSD) values were calculated at 5\% probability and Duncan's letter. 


\section{Results and Discussion}

\subsection{Physical Properties of Juice Quality}

According to results given in Figures 1-4 pointed out that formula of juice extracted from sugar cane and sweet sorghum and some clarification treatments had a significant effect on physical properties of juice expressed as total soluble solids percentage (TSS\%), purity\%, color (Icumsa units) and $\mathrm{pH}$ value. The formula of juice $\left(\mathrm{A}_{1}\right)$ composed of $100 \%$ cane juice $(\mathrm{CJ})$ and $0.0 \%$ sorghum juice $(\mathrm{SJ})$ contained the highest values of $\mathrm{TSS} \%$, purity $\%, \mathrm{pH}$ value and the lowest value of color $(21.73,78.90,5.74 \%$ and. 636.00 ICUMSA, respectively). While, the formula of juice $\left(\mathrm{A}_{5}\right)$ composed of $0.0 \% \mathrm{CJ}$ and $100 \% \mathrm{SJ}$ contained the lowest values of TSS $\%$, purity $\%, \mathrm{pH}$ value and the highest value of color $(18.38,69.58,5.38 \%$ and. 728.36 ICUMSA, respectively). This finding is might be attributed to CJ had the highest value of sucrose and the lowest value of nonsucrose substances and the reverse related to SJ. The obtained results are in general acceptance with those recorded by [2]. In this respect, [3, 24] clarified that the food quality is given by a set of quantitative and qualitative characters, doing acceptable for the consumers. When the quantity of insoluble solids is reduced, the color and presentation improve.

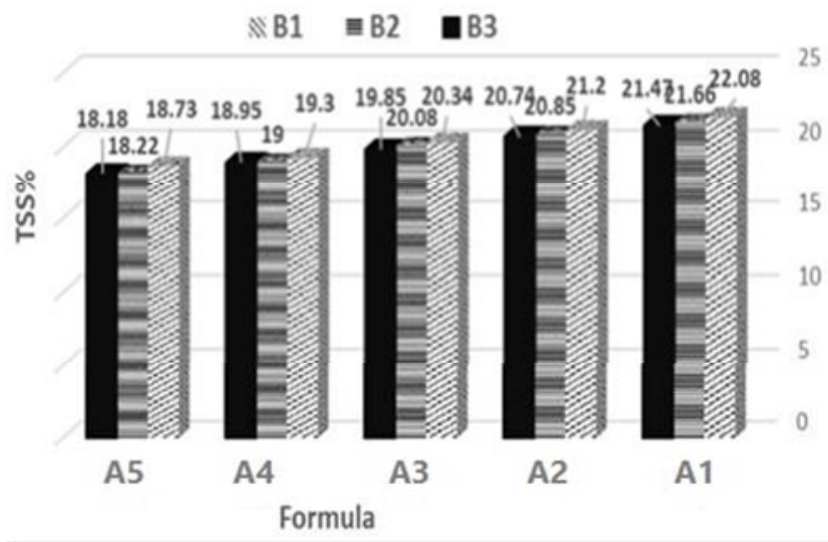

Figure 1. Effect of formula and clarification on TSS\% of juice.

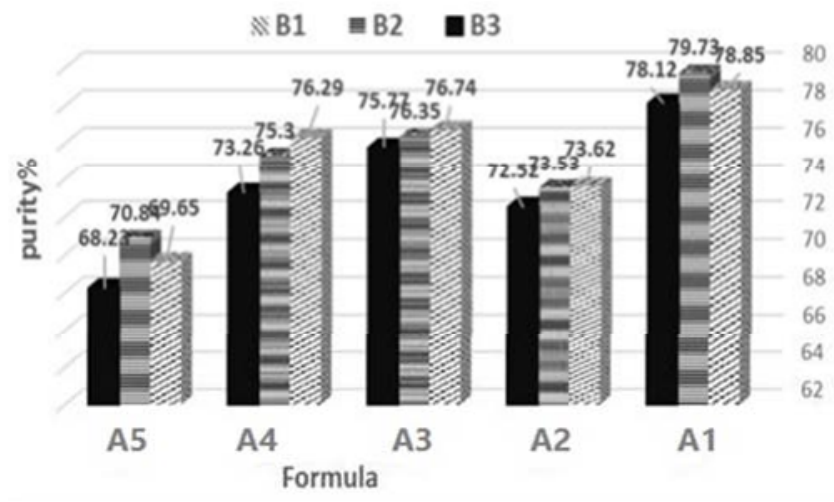

Figure 2. Effect of formula and clarification on purity\% of juice.

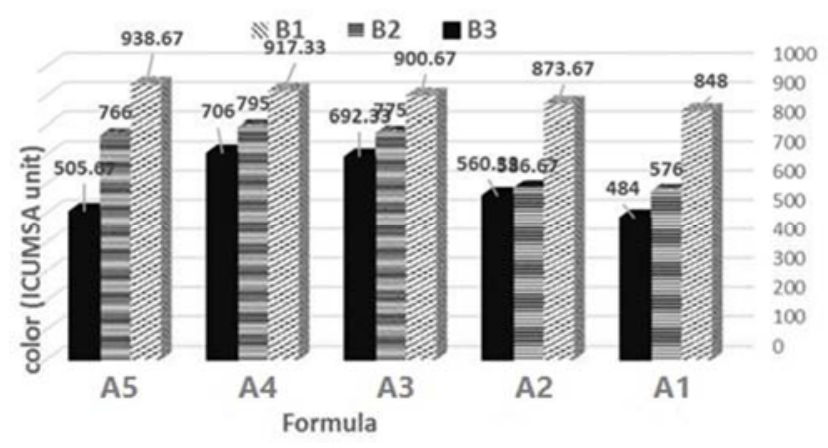

Figure 3. Effect of formula and clarification on color of juice.

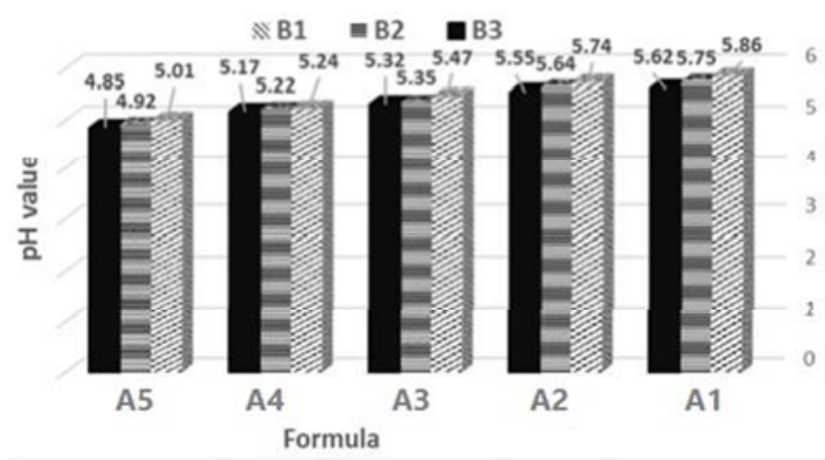

Figure 4. Effect of formula and clarification on $\mathrm{pH}$ value of juice.

Figures 1-4. Effect of formula and clarification treatments on $\mathrm{TSS} \%$, purity $\%$, color and $\mathrm{pH}$ value of juice extracted from sugar cane and sweet sorghum.

Whereas: $\mathrm{A} 1=100 \% \mathrm{CJ}, \mathrm{A} 2=75 \% \mathrm{CJ}: 25 \% \mathrm{SJ}, \mathrm{A} 3=$ $50 \%$ CJ: $50 \%$ SJ, A4 = 25\% CJ: $75 \%$ SJ and A5 = 100\% SJ.

$\mathrm{B} 1=$ untreated (control), B2 = pre-heating of juice, $80 \pm 0.50^{\circ} \mathrm{C}$ for 10 minutes, $\mathrm{B} 3=0.05 \%$ citric acid. $\mathrm{CJ}=\mathrm{Cane}$ juice $\mathrm{SJ}=$ Sorghum juice

Data recorded in Figures 1-4 revealed that juice clarification treatment of pre-heating at $80 \pm 0.50^{\circ} \mathrm{C}\left(\mathrm{B}_{2}\right)$ recorded the highest value of purity\% (75.15\%) and treatment of juice by $0.05 \%$ citric acid $\left(\mathrm{B}_{3}\right)$ contained the lowest value of color (589.67 ICUMSA), while control treatment $\left(B_{1}\right)$ scored the highest values of TSS\% $(20.33 \%)$ and $\mathrm{pH}$ value (5.47) and color (895.67 ICUMSA). This result was might be attributed to the control treatment contained the highest value of impurities. The obtained results are in general acceptance with those recorded by [3]. They reported that the citric acid was able to reduce $\mathrm{pH}$ value of sugarcane juice to 4.9 which gave a preservative action and inhibit the growth of micro-organism during storage. In this subject [24] indicated that darkening of sugarcane juice occurs by formation of brown pigments by enzymatic (oxidation of phenolic compounds forming melanin) and non-enzymatic reactions (Maillard reaction, thermal and alkaline degradation and sugar condensation). They clarified that the reddish color of juice is due to a component of phenolic character and can exist in a free manner or glycosides attached to sugar molecules.

A significant interactions between formula of juice (A) and clarification treatments (B) with regard to physical properties of juice quality except TSS\% as shown in Figures 1-4. It 
could be revealed from the data that use of formula $\left(A_{1}\right)$ composed of $100 \% \mathrm{CJ}$ and $0.00 \% \mathrm{SJ}$ with clarification treatment of pre-heating at $80 \pm 0.50^{\circ} \mathrm{C}\left(\mathrm{B}_{2}\right)$ recorded the highest value of purity\% (79.73). Such data confirmed the previous reports of $[3,26]$. They studied that conventional heat processing imparts the taste of juice and the delicate flavour of juice is adversely affected. Polyphenol oxidase is the major enzyme involved in the discoloration of sugarcane juice which can be improved by heat inactivation of enzyme. Addition of citric acid gave good pleasant dull orange colour to juice. $[16,19]$ demonstrated that the goals of juice clarification are to: (i) stabilize juice with respect to microbial deterioration, (ii) remove suspended and turbid particles, and (iii) allow subsequent concentration of the clarified juice (CJ) into a viable liquid product using standard commercial evaporation technologies.

\subsection{Chemical Compsition}

With regard to data scored in Table 1 and Figures 5-9 pointed out that formula of juice extracted from sugar cane and sweet sorghum and some clarification treatments had a significant effect on chemical composition of juice expressed as moisture $\%$, sucrose $\%$, reducing sugars $\%$, crude protein $\%$, total lipids, ash $\%$ and titratable acidity. Formula $\left(\mathrm{A}_{1}\right)$ contained the highest values of sucrose $\%(17.15 \%)$, total lipids\% $\%(0.44 \%)$, ash\% $(0.61 \%)$ and the lowest values of moisture, reducing sugars $\%$ and titratable acidity $(78.61 \%$, $0.48 \%$ and 0.22 , respectively). Besides, the highest values of mineral composition, i.e. contents of $\mathrm{K}, \mathrm{Na}, \mathrm{Ca}, \mathrm{Mg}$ (410.67, $21.22,61.33,43.22 \mathrm{mg} / 100 \mathrm{~g})$ and $\mathrm{Fe}(9.11 \mathrm{ppm})$ were scored in Formula $\left(\mathrm{A}_{1}\right)$, While, formula $\left(\mathrm{A}_{5}\right)$ contained the lowest values of sucrose $\%(12.79 \%)$, total lipids $\%(0.28 \%)$, ash $\%$ $(0.37 \%)$, contents of $\mathrm{K}, \mathrm{Na}, \mathrm{Ca}, \mathrm{Mg}(328.78,9.89,42.56$, $29.44 \mathrm{mg} / 100 \mathrm{~g}), \mathrm{Fe}(7.11 \mathrm{ppm})$ and the highest values of moisture, reducing sugars $\%$ and titratable acidity $(82.75 \%$, $2.39 \%$ and 0.44 , respectively). Also, This finding was might be attributed to the formula $\left(A_{1}\right)$ had the highest value of purity $\%$, ash $\%$ and the reverse related to formula $\left(\mathrm{A}_{5}\right)$. The obtained results are in general acceptance with those recorded by $[3,6,19]$. In this subject, $[4,13,15,21]$ demonstrated that sugarcane juice contained very small quantities of protein $(0.39-0.60 \%)$ and fat $(0.14-0.19 \%)$, while sorghum juice contains 13 to $17 \%$ sugar, of which 10 to $14 \%$ is sucrose.

Table 1. Effect of juice formula extracted from sugar cane and sweet sorghum and clarification treatments on juice chemical composition.

\begin{tabular}{|c|c|c|c|c|c|c|c|c|}
\hline \multirow[b]{2}{*}{ Formula (A) } & \multirow{2}{*}{$\begin{array}{l}\text { Clarification } \\
\text { treatments (B) }\end{array}$} & \multicolumn{7}{|c|}{ Chemical composition of mixture juice (MJ) } \\
\hline & & Moisture\% & Sucrose $\%$ & $\begin{array}{l}\text { Reducing } \\
\text { sugars } \%\end{array}$ & $\begin{array}{l}\text { Crude } \\
\text { protein } \%\end{array}$ & $\begin{array}{l}\text { Total } \\
\text { lipids\% }\end{array}$ & Ash\% & $\begin{array}{l}\text { Titratable } \\
\text { acidity }\end{array}$ \\
\hline \multirow{4}{*}{$\mathrm{A}_{1}$} & $\mathrm{~B}_{1}$ & 78.3 o & $17.41 \mathrm{a}$ & $0.38 \mathrm{~m}$ & 0.28 ef & $0.70 \mathrm{a}$ & $0.76 \mathrm{a}$ & $0.17 \mathrm{i}$ \\
\hline & $\mathrm{B}_{2}$ & $78.90 \mathrm{~m}$ & $17.27 \mathrm{~b}$ & 0.481 & $0.21 \mathrm{fg}$ & $0.35 \mathrm{f}$ & $0.57 \mathrm{~d}$ & $0.20 \mathrm{~h}$ \\
\hline & $\mathrm{B}_{3}$ & $78.63 n$ & $16.77 \mathrm{c}$ & $0.59 \mathrm{k}$ & $0.16 \mathrm{~g}$ & $0.27 \mathrm{~g}$ & $0.51 \mathrm{~g}$ & $0.29 \mathrm{e}$ \\
\hline & Mean & $78.61 \mathrm{e}$ & $17.15 \mathrm{a}$ & $0.48 \mathrm{e}$ & $0.22 \mathrm{c}$ & $0.44 \mathrm{a}$ & $0.61 \mathrm{a}$ & $0.22 \mathrm{e}$ \\
\hline \multirow{4}{*}{$\mathrm{A}_{2}$} & $\mathrm{~B}_{1}$ & 79.211 & $15.61 \mathrm{~d}$ & 0.481 & $0.30 \mathrm{e}$ & $0.65 \mathrm{~b}$ & $0.70 \mathrm{~b}$ & $0.22 \mathrm{~h}$ \\
\hline & $\mathrm{B}_{2}$ & $79.76 \mathrm{j}$ & $15.33 \mathrm{e}$ & $0.76 \mathrm{j}$ & $0.21 \mathrm{fg}$ & $0.28 \mathrm{~g}$ & $0.54 \mathrm{e}$ & $0.26 \mathrm{fg}$ \\
\hline & $\mathrm{B}_{3}$ & $79.52 \mathrm{k}$ & $15.04 \mathrm{f}$ & $0.90 \mathrm{i}$ & $0.16 \mathrm{~g}$ & $0.21 \mathrm{hi}$ & $0.48 \mathrm{~h}$ & $0.34 \mathrm{~d}$ \\
\hline & Mean & $79.50 \mathrm{~d}$ & $15.33 b$ & $0.71 \mathrm{~d}$ & $0.22 \mathrm{c}$ & $0.38 \mathrm{~b}$ & $0.58 \mathrm{~b}$ & $0.27 \mathrm{~d}$ \\
\hline \multirow{4}{*}{$\mathrm{A}_{3}$} & $\mathrm{~B}_{1}$ & $80.10 \mathrm{i}$ & $15.61 \mathrm{~d}$ & $1.21 \mathrm{~h}$ & $0.43 \mathrm{~b}$ & $0.54 \mathrm{c}$ & $0.66 \mathrm{c}$ & $0.25 \mathrm{~g}$ \\
\hline & $\mathrm{B}_{2}$ & $80.92 \mathrm{~g}$ & $15.33 \mathrm{e}$ & $1.40 \mathrm{~g}$ & $0.30 \mathrm{e}$ & $0.23 \mathrm{~h}$ & $0.52 \mathrm{fg}$ & $0.27 \mathrm{f}$ \\
\hline & $\mathrm{B}_{3}$ & $80.76 \mathrm{~h}$ & $15.04 \mathrm{f}$ & $1.61 \mathrm{f}$ & $0.34 \mathrm{cde}$ & $0.26 \mathrm{~g}$ & $0.46 \mathrm{i}$ & $0.38 \mathrm{c}$ \\
\hline & Mean & $80.59 \mathrm{c}$ & $15.33 \mathrm{c}$ & $1.41 \mathrm{c}$ & $0.36 \mathrm{~b}$ & $0.35 \mathrm{c}$ & $0.55 \mathrm{c}$ & $0.30 \mathrm{c}$ \\
\hline \multirow{4}{*}{$\mathrm{A}_{4}$} & $\mathrm{~B}_{1}$ & $81.08 \mathrm{f}$ & $14.72 \mathrm{~g}$ & $1.85 \mathrm{e}$ & $0.42 \mathrm{~b}$ & $0.50 \mathrm{~d}$ & $0.58 \mathrm{~d}$ & $0.33 \mathrm{~d}$ \\
\hline & $\mathrm{B}_{2}$ & $81.61 d$ & $14.31 \mathrm{~h}$ & $1.93 \mathrm{e}$ & $0.31 \mathrm{de}$ & $0.20 \mathrm{ig}$ & $0.47 \mathrm{hi}$ & $0.38 \mathrm{c}$ \\
\hline & $\mathrm{B}_{3}$ & $81.38 \mathrm{e}$ & $13.88 \mathrm{i}$ & $2.03 \mathrm{~d}$ & $0.38 \mathrm{bcd}$ & $0.23 \mathrm{~h}$ & $0.43 \mathrm{j}$ & $0.43 \mathrm{~b}$ \\
\hline & Mean & $81.36 b$ & $14.30 \mathrm{~d}$ & $1.94 \mathrm{~b}$ & $0.37 \mathrm{ab}$ & $0.31 \mathrm{~d}$ & $0.49 \mathrm{~d}$ & $0.38 \mathrm{~b}$ \\
\hline \multirow{4}{*}{$\mathrm{A}_{5}$} & $\mathrm{~B}_{1}$ & $82.15 \mathrm{c}$ & $13.04 \mathrm{j}$ & $2.18 \mathrm{c}$ & $0.54 \mathrm{a}$ & $0.44 \mathrm{e}$ & $0.54 \mathrm{ef}$ & $0.37 \mathrm{c}$ \\
\hline & $\mathrm{B}_{2}$ & $83.17 \mathrm{a}$ & $12.91 \mathrm{k}$ & $2.39 \mathrm{~b}$ & $0.29 \mathrm{e}$ & $0.18 \mathrm{j}$ & $0.31 \mathrm{k}$ & $0.43 \mathrm{~b}$ \\
\hline & $\mathrm{B}_{3}$ & $82.91 b$ & 12.411 & $2.61 \mathrm{a}$ & $0.40 \mathrm{bc}$ & $0.21 \mathrm{hi}$ & 0.271 & $0.52 \mathrm{a}$ \\
\hline & Mean & $82.75 a$ & $12.79 \mathrm{e}$ & $2.39 \mathrm{a}$ & $0.41 \mathrm{a}$ & $0.28 \mathrm{e}$ & $0.37 \mathrm{e}$ & $0.44 \mathrm{a}$ \\
\hline \multirow{3}{*}{ Means of B } & $\mathrm{B}_{1}$ & $80.17 \mathrm{c}$ & $15.28 \mathrm{a}$ & $1.22 \mathrm{c}$ & $0.39 \mathrm{a}$ & $0.57 \mathrm{a}$ & $0.65 \mathrm{a}$ & $0.27 \mathrm{c}$ \\
\hline & $\mathrm{B}_{2}$ & $80.87 \mathrm{a}$ & $15.03 \mathrm{~b}$ & $1.39 \mathrm{~b}$ & $0.27 \mathrm{~b}$ & $0.25 \mathrm{~b}$ & $0.48 \mathrm{~b}$ & $0.31 \mathrm{~b}$ \\
\hline & $\mathrm{B}_{3}$ & $80.64 b$ & $14.63 \mathrm{c}$ & $1.55 \mathrm{a}$ & $0.29 \mathrm{~b}$ & $0.24 b$ & $0.43 \mathrm{c}$ & $0.39 \mathrm{a}$ \\
\hline \multirow[t]{2}{*}{ Overall mean } & & 80.56 & 14.98 & 1.39 & 0.32 & 0.35 & 0.52 & 0.32 \\
\hline & A & 0.08 & 0.06 & 0.06 & 0.05 & 0.013 & 0.015 & 0.009 \\
\hline \multirow[t]{2}{*}{ LSD 0.05} & B & 0.045 & 0.038 & 0.02 & 0.02 & 0.012 & 0.009 & 0.008 \\
\hline & $\mathrm{AB}$ & 0.10 & 0.084 & 0.09 & 0.07 & 0.026 & 0.021 & 0.018 \\
\hline
\end{tabular}

$\mathrm{A}_{1}=100.00 \% \mathrm{CJ}: 0.00 \% \mathrm{SJ}, \mathrm{A}_{2}=75.00 \% \mathrm{CJ}: 0.25 \% \mathrm{SJ}, \mathrm{A}_{3}=50.00 \% \mathrm{CJ}: 50.00 \% \mathrm{SJ}, \mathrm{A}_{4}=25.00 \% \mathrm{CJ}: 75.00 \% \mathrm{SJ}$ and $\mathrm{A}_{5}=0.00 \% \mathrm{CJ}: 100.00 \% \mathrm{SJ}$.

$\mathrm{B}_{1}=$ untreated, control, $\mathrm{B}_{2}=$ pre-heating of juice, $80 \pm 0.50^{\circ} \mathrm{C}$ for 10 minutes, and $\mathrm{B}_{3}=0.05 \%$ citric acid. CJ $=\mathrm{Cane}$ juice $\mathrm{SJ}=\mathrm{Sorghum}$ juice Ns $=\mathrm{Non}-$ significant 
Figures 5-9. Effect of formula and clarification treatments on juice extracted from sugar cane and sweet sorghum mineral composition (K, Na, Ca, Mg (mg/ 100 g DWB) and Fe.

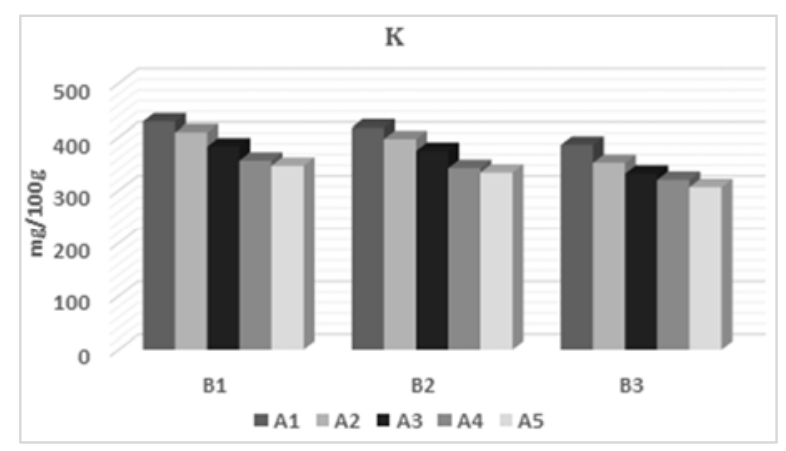

Figure 5. Effect of formula and clarification on $K(\mathrm{mg} / \mathrm{log})$ of juice.

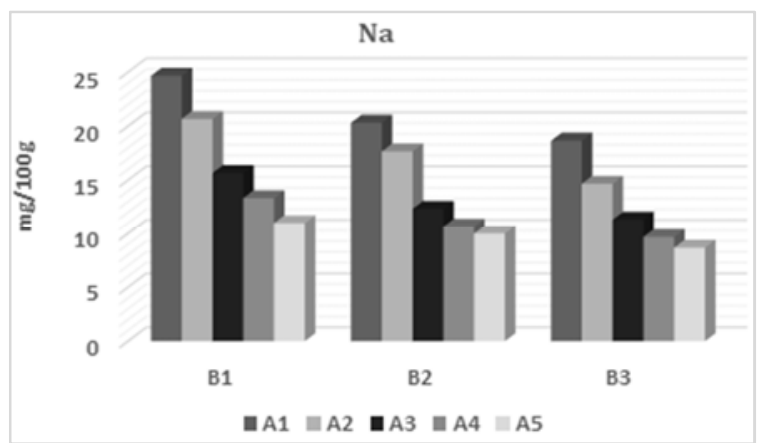

Figure 6. Effect of formula and clarification on $\mathrm{Na}(\mathrm{mg} / 100 \mathrm{~g})$ of juice.

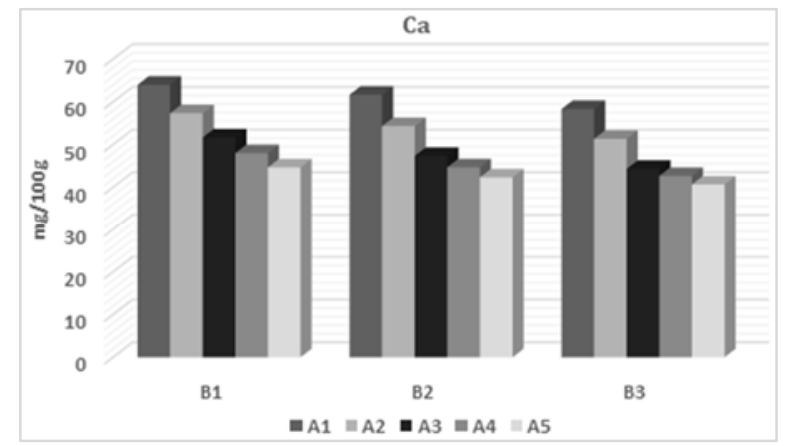

Figure 7. Effect of formula and clarification on $\mathrm{Ca}(\mathrm{mg} / \mathrm{l00g})$ of juice.

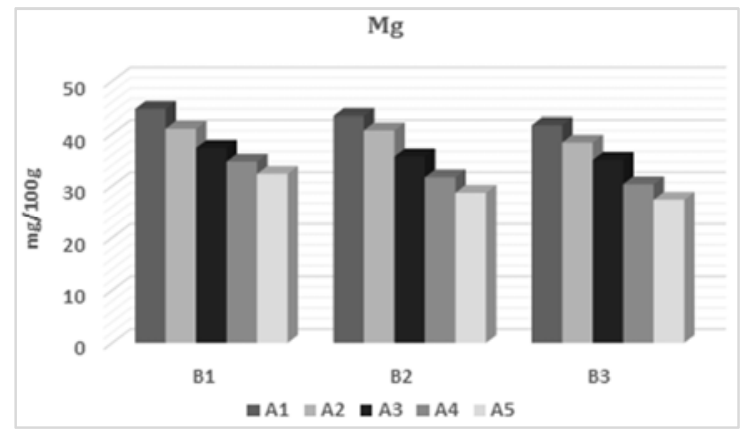

Figure 8. Effect of formula and clarification on $\mathrm{Mg}(\mathrm{mg} / 100 \mathrm{~g})$ of juice.

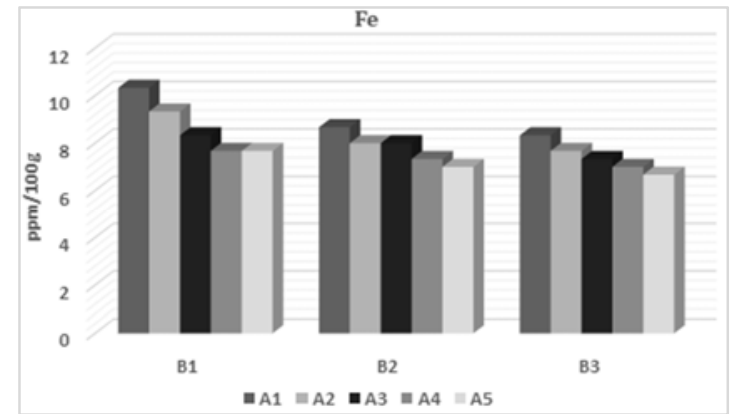

Figure 9. Effect of formula and clarification on $\mathrm{Fe}$ (ppm) of juice.

Data in Table 1 and Figures 5-9 showed that clarification treatment of juice $\left(\mathrm{B}_{3}\right)$ recorded the highest value of reducing sugars $\%(1.55 \%)$ and titratable acidity (0.39), while the highest values of sucrose $\%(15.28 \%)$ and crude protein $(0.39 \%)$, total lipids $(0.57 \%)$ and ash $(0.52 \%)$ as well as mineral composition, i.e. contents of $\mathrm{K}, \mathrm{Na}, \mathrm{Ca}, \mathrm{Mg}$ (384.47, 17.07, 53.13, $38.00 \mathrm{mg} / 100 \mathrm{~g})$ and $\mathrm{Fe}(8.67 \mathrm{ppm})$ were scored with control treatment $\left(\mathrm{B}_{1}\right)$. This result was might be attributed to that clarification treatment of juice $\left(B_{3}\right)$ led to break a portion of sucrose into reducing sugars (glucose and fructose), while the the control treatment $\left(\mathrm{B}_{1}\right)$ contained the highest value of the purity $\%$, ash $\%$ and non-sucrose substances. The obtained findings are in general acceptance with those recorded by $[1,11]$.

A significant interactions between formula (A) and clarification treatments (B) with regard to chemical and mineral composition of juice quality except $\mathrm{Mg}$ and $\mathrm{Fe}$ elments are scored in Table 1 and Figures 5-9. It could be revealed from the data that use of formula $\left(A_{5}\right)$ with clarification treatment $\left(\mathrm{B}_{3}\right)$ recorded the highest value of reducing sugars\% $(2.61 \%)$ and titratable acidity (0.52). In general, it is such data confirmed the previous reports of [7, 20]. They showed that the quality and availability are associated to the food safety, especially harmless and nutritious food.

\subsection{Sensory Evaluation}

Regarding data given in Table 2 demonstrated that the formula of juice extracted from sugar cane and sweet sorghum and some clarification treatments had a significant effect on sensory properties of juice expressed as taste, consistency, flavor and preference. Formula $\left(\mathrm{A}_{1}\right)$ contained the highest values of taste (23.92), flavor (22.71), preference (23.12) and the lowest value of consistency (19.80). While, the highest value of consistency (23.27) was sored in Formula $\left(\mathrm{A}_{5}\right)$. This finding is might be attributed to that Formula $\left(A_{1}\right)$ had the highest value of sucrose $\%$ and the reverse related to formula $\left(A_{5}\right)$. The obtained results are in general acceptance with those recorded by $[3,10]$.

Data in Table 2 showed that clarification treatment $\left(\mathrm{B}_{2}\right)$ recorded the highest value of taste (21.34), flavor (21.47) and perference (22.05), while the lowest values of taste (20.34) and perference (20.95) were scored with control treatment $\left(B_{1}\right)$. This result is might be attributed to the the treatment 
$\left(B_{2}\right)$ led to break a portion of sucrose into glucose and fructose caused the highest value of the taste and perference. The obtained findings are in general acceptance with those recorded by [3]. They demonstrated that this phenomenon is due to a break of the weak glucoside link.

A significant interactions between formula of juice (A) and clarification treatments $(\mathrm{B})$ with regard to sensory properties of juice except taste are scored in Table 4. It could be revealed from the data that use of formula $\left(A_{2}\right)$ with clarification treatment $\left(B_{2}\right)$ recorded the highest value of taste
(22.70), flavor (23.17) and preference (23.80). Such data confirmed the previous reports of [3]. They indicated that addition of citric acid to juice also gave good pleasant dull orange colour to juice. [15] noticed that sugar cane juice is highly nutritious, containing natural sugars, several minerals, vitamins, amino acids, organic acids, starch, phosphatides, and gums. They indicated that sugar cane juice cannot be stored normally for more than $6 \mathrm{~h}$ and commercially it has short shelf life.

Table 2. Effect of juice formula extracted from sugar cane and sweet sorghum and clarification treatments on juice sensory properties.

\begin{tabular}{|c|c|c|c|c|c|}
\hline \multirow{2}{*}{ Formula (A) } & \multirow{2}{*}{ Clarification treatments (B) } & \multicolumn{4}{|c|}{ Sensory properties of juice } \\
\hline & & Taste & Consistency & Flavor & Preference \\
\hline \multirow{4}{*}{ A1 } & $\mathrm{B} 1$ & $23.37 \mathrm{e}$ & $22.20 \mathrm{~g}$ & $22.03 \mathrm{~d}$ & $22.00 \mathrm{~d}$ \\
\hline & $\mathrm{B} 2$ & $24.40 \mathrm{e}$ & $20.97 \mathrm{i}$ & $22.73 \mathrm{~b}$ & $23.30 \mathrm{~b}$ \\
\hline & B3 & $24.00 \mathrm{ef}$ & $20.63 \mathrm{j}$ & $21.60 \mathrm{e}$ & $22.63 \mathrm{c}$ \\
\hline & Mean & $23.92 \mathrm{a}$ & $21.27 \mathrm{~d}$ & $22.12 \mathrm{~b}$ & $22.64 \mathrm{~b}$ \\
\hline \multirow{4}{*}{ A2 } & B1 & $21.80 \mathrm{abc}$ & $20.43 \mathrm{k}$ & $22.70 \mathrm{~b}$ & $22.50 \mathrm{c}$ \\
\hline & $\mathrm{B} 2$ & $22.70 \mathrm{a}$ & 19.771 & $23.17 \mathrm{a}$ & $23.80 \mathrm{a}$ \\
\hline & B3 & $22.97 \mathrm{ab}$ & $19.20 \mathrm{~h}$ & $22.27 \mathrm{c}$ & $23.07 \mathrm{~b}$ \\
\hline & Mean & $22.49 \mathrm{~b}$ & $19.80 \mathrm{e}$ & $22.71 \mathrm{a}$ & $23.12 \mathrm{a}$ \\
\hline \multirow{4}{*}{ A3 } & B1 & $22.17 \mathrm{~cd}$ & $23.00 \mathrm{c}$ & $20.83 \mathrm{f}$ & $21.67 \mathrm{ef}$ \\
\hline & $\mathrm{B} 2$ & $21.33 \mathrm{bcd}$ & $22.23 \mathrm{~g}$ & $21.57 \mathrm{e}$ & $22.53 \mathrm{c}$ \\
\hline & B3 & $20.90 \mathrm{~d}$ & $21.77 \mathrm{~h}$ & $20.13 \mathrm{~g}$ & $21.83 \mathrm{~d}$ \\
\hline & Mean & $20.80 \mathrm{c}$ & $22.33 \mathrm{c}$ & $20.84 \mathrm{c}$ & $21.84 \mathrm{c}$ \\
\hline \multirow{4}{*}{ A4 } & B1 & $18.60 \mathrm{i}$ & $23.37 \mathrm{~b}$ & $19.10 \mathrm{i}$ & $20.67 \mathrm{~g}$ \\
\hline & B2 & $19.60 \mathrm{~h}$ & $22.73 \mathrm{e}$ & $20.27 \mathrm{~g}$ & $21.23 \mathrm{e}$ \\
\hline & B3 & $19.30 \mathrm{ij}$ & $22.37 \mathrm{f}$ & $18.80 \mathrm{j}$ & $20.93 \mathrm{f}$ \\
\hline & Mean & $19.17 \mathrm{~d}$ & $22.82 \mathrm{~b}$ & $19.39 \mathrm{~d}$ & $20.94 \mathrm{~d}$ \\
\hline \multirow{4}{*}{ A5 } & B1 & $17.77 \mathrm{fgh}$ & $23.87 \mathrm{a}$ & $18.30 \mathrm{k}$ & $18.43 \mathrm{j}$ \\
\hline & $\mathrm{B} 2$ & $18.67 \mathrm{gh}$ & $23.07 \mathrm{c}$ & $19.60 \mathrm{~h}$ & $19.37 \mathrm{~h}$ \\
\hline & B3 & $18.17 \mathrm{~h}$ & $22.87 \mathrm{~d}$ & 17.531 & $18.73 \mathrm{i}$ \\
\hline & Mean & $18.20 \mathrm{e}$ & $23.27 \mathrm{a}$ & $18.48 \mathrm{e}$ & $18.84 \mathrm{e}$ \\
\hline \multirow{3}{*}{ Means of B } & B1 & $20.34 c$ & $22.57 \mathrm{a}$ & $20.59 \mathrm{~b}$ & $20.95 \mathrm{c}$ \\
\hline & B2 & $21.34 \mathrm{a}$ & $21.75 b$ & $21.47 \mathrm{a}$ & $22.05 \mathrm{a}$ \\
\hline & B3 & $21.07 \mathrm{~b}$ & $21.37 \mathrm{c}$ & $20.07 \mathrm{c}$ & $21.44 \mathrm{~b}$ \\
\hline \multirow[t]{2}{*}{ Overall mean } & & 20.92 & 21.90 & 20.71 & 21.48 \\
\hline & A & 0.13 & 0.07 & 0.10 & 0.14 \\
\hline \multirow[t]{2}{*}{ LSD 0.05} & B & 0.09 & 0.08 & 0.08 & 0.07 \\
\hline & $\mathrm{AB}$ & 0.38 & 0.12 & 0.17 & 0.23 \\
\hline
\end{tabular}

$\mathrm{A}_{1}=100.00 \% \mathrm{CJ}: 0.00 \% \mathrm{SJ}, \mathrm{A}_{2}=75.00 \% \mathrm{CJ}: 0.25 \% \mathrm{SJ}, \mathrm{A}_{3}=50.00 \% \mathrm{CJ}: 50.00 \% \mathrm{SJ}, \mathrm{A}_{4}=25.00 \% \mathrm{CJ}: 75.00 \% \mathrm{SJ}$ and $\mathrm{A}_{5}=0.00 \% \mathrm{CJ}: 100.00 \% \mathrm{SJ}$.

$\mathrm{B}_{1}=$ untreated, control, $\mathrm{B} 2=$ pre-heating of juice, $80 \pm 0.50^{\circ} \mathrm{C}$ for 10 minutes, and $\mathrm{B} 3=0.05 \%$ citric acid. CJ $=\mathrm{Cane}$ juice $\mathrm{SJ}=\mathrm{Sorghum}$ juice Ns $=\mathrm{Non}-$ significant

\subsection{Correlatios Among the Studied Juice Physiochemical Properties}

Regarding data given in Table 3 and Figure 10 clarified that an increase in TSS\%of juice were correlated by a highly significant increase in sucrose $\%$, ash $\%, \mathrm{pH}$ value, purity $\%$, contents of $\mathrm{K}, \mathrm{Na}, \mathrm{Ca}, \mathrm{Mg}(\mathrm{mg} / 100 \mathrm{~g} \mathrm{DWB})$ and $\mathrm{Fe}$ (ppm) of juice, significant increase in total lipids $\%$ of juice, highly significant decrease in reducing sugars $\%$ and titratable acidity of juice, a significant decrease in total protein $\%$ of juice and nonsignificant decrease in color of juice extracted from sugar cane and sweet sorghum at different formula and clarification treatments. This result might be attributed to there was a positive relationship $\mathrm{TSS} \%$ and both of sucrose $\%$, ash $\%$ and purity $\%$. The obtained findings are in acceptance with [10].

Table 3. Correlations of physical with physiochemical properties of juice.

\begin{tabular}{lllll}
\hline Correlations & TSS\% & Color & pH & Purity \\
\hline Moisture & $-1.000^{* *}$ & 0.207 & $-.961^{* *}$ & $-.714^{* *}$ \\
TSS & 1 & -0.207 & $.961^{* *}$ & $.714^{* *}$ \\
Sucrose & $.944^{* *}$ & -0.047 & $.951^{* *}$ & $.858^{* *}$ \\
Reducing sugar & $-.975^{* *}$ & 0.107 & $-.996^{* *}$ & $-.732^{* *}$ \\
Protein & $-.625 *$ & $.637 *$ & $-.620^{*}$ & -0.29 \\
Lipid & $.568^{*}$ & 0.511 & $.593 *$ & 0.5 \\
Ash & $.654^{* *}$ & $.532^{*}$ & $.743 * *$ & $.600^{*}$ \\
\hline
\end{tabular}




\begin{tabular}{lllll}
\hline Correlations & TSS\% & Color & pH & Purity \\
\hline Titratable Acidity & $-.825^{* *}$ & -0.214 & $-.911^{* *}$ & $-.732^{* *}$ \\
Color & -0.207 & 1 & -0.093 & 0.046 \\
$\mathrm{pH}$ & $.961^{* *}$ & -0.093 & 1 & $.707^{* *}$ \\
Purity & $.714^{* *}$ & 0.046 & $.707^{* *}$ & 1 \\
$\mathrm{~K}$ & $.832^{* *}$ & 0.136 & $.914^{* *}$ & $.696^{* *}$ \\
$\mathrm{Na}$ & $.929^{* *}$ & 0.054 & $.961^{* *}$ & $.693^{* *}$ \\
$\mathrm{Ca}$ & $.924^{* *}$ & 0.02 & $.947^{* *}$ & $.733^{* *}$ \\
$\mathrm{Mg}$ & $.971^{* *}$ & -0.1 & $.979^{* *}$ & $.721^{* *}$ \\
$\mathrm{Fe}$ & $.860^{* *}$ & 0.196 & $.906^{* *}$ & $.725^{* *}$ \\
\hline
\end{tabular}

** Correlation is significant at the 0.01 level (2-tailed).

* Correlation is significant at the 0.05 level (2-tailed).

Results in Table 4 and Figure 10 clarified that an increase in sucrose $\%$ of juice were correlated by a highly significant increase in TSS\%, ash $\%, \mathrm{pH}$ value, purity $\%$, contents of $\mathrm{K}$, $\mathrm{Na}, \mathrm{Ca}, \mathrm{Mg}$ (mg/100g DWB) and $\mathrm{Fe}$ (ppm) of juice, significant increase in total lipids $\%$ of juice, highly significant decrease in reducing sugars $\%$ and titratable acidity of juice and nonsignificant decrease in total protein $\%$ and color of juice extracted from sugar cane and sweet sorghum at different formula and clarification treatments. This result might be attributed to there was a negative relationship between sucrose $\%$ and both of reducing sugars $\%$ and titratable acidity of juice. These findings are in same line with results of [15].

Table 4. Correlations of chemical composition with physiochemical properties of juice.

\begin{tabular}{|c|c|c|c|c|c|c|c|}
\hline Correlations & Moisture\% & Sucrose\% & $\begin{array}{l}\text { Reducing } \\
\text { sugars } \%\end{array}$ & Protein \% & Lipid\% & Ash\% & $\begin{array}{l}\text { Titratable } \\
\text { Acidity }\end{array}$ \\
\hline Moisture $\%$ & 1 & $-.944 * *$ & $.975^{* *}$ & $.625 *$ & $-.568 *$ & $-.654 * *$ & $.825 * *$ \\
\hline Sucrose $\%$ & $-.944 * *$ & 1 & $-.963 * *$ & -0.512 & $.628 *$ & $.743 * *$ & $-.917 * *$ \\
\hline Reducing sugars $\%$ & $.975 * *$ & $-.963 * *$ & 1 & $.627 *$ & $-.590 *$ & $-.732 * *$ & $.904 * *$ \\
\hline Protein $\%$ & $.625^{*}$ & -0.512 & $.627^{*}$ & 1 & 0.178 & -0.043 & 0.362 \\
\hline Lipid\% & $-.568 *$ & $.628 *$ & $-.590 *$ & 0.178 & 1 & $.899 * *$ & $-.761 * *$ \\
\hline Ash $\%$ & $-.654 * *$ & $.743 * *$ & $-.732 * *$ & -0.043 & $.899 * *$ & 1 & $-.911 * *$ \\
\hline TSS $\%$ & $-1.000 * *$ & $.944 * *$ & $-.975 * *$ & $-.625^{*}$ & $.568 *$ & $.654 * *$ & $-.825 * *$ \\
\hline Color & 0.207 & -0.047 & 0.107 & $.637 *$ & 0.511 & $.532 *$ & -0.214 \\
\hline $\mathrm{pH}$ value & $-.961 * *$ & $.951 * *$ & $-.996 * *$ & $-.620^{*}$ & $.593 *$ & $.743 * *$ & $-.911 * *$ \\
\hline Purity\% & $-.714 * *$ & $.858 * *$ & $-.732 * *$ & -0.29 & 0.5 & $.600 *$ & $-.732 * *$ \\
\hline $\mathrm{K}(\mathrm{mg} / 100 \mathrm{~g})$ & $-.832 * *$ & $.899 * *$ & $-.911 * *$ & -0.483 & $.699 * *$ & $.871 * *$ & $-.971 * *$ \\
\hline $\mathrm{Na}(\mathrm{mg} / 100 \mathrm{~g})$ & $-.929 * *$ & $.933 * *$ & $-.964 * *$ & $-.519 *$ & $.717 * *$ & $.843 * *$ & $-.946 * *$ \\
\hline $\mathrm{Ca}(\mathrm{mg} / 100 \mathrm{~g})$ & $-.924 * *$ & $.934 * *$ & $-.954 * *$ & $-.534 *$ & $.678 * *$ & $.826 * *$ & $-.929 * *$ \\
\hline
\end{tabular}

** Correlation is significant at the 0.01 level (2-tailed).

* Correlation is significant at the 0.05 level (2-tailed).

Data in Table 5 and Figure 10 clarified that an increase in Fe content (ppm) of juice were correlated by a highly significant increase in $\mathrm{TSS} \%$, sucrose $\%$, total lipids $\%$, ash $\%$, $\mathrm{pH}$ value, purity $\%$, contents of $\mathrm{K}, \mathrm{Na}, \mathrm{Ca}$ and $\mathrm{Mg}(\mathrm{mg} / 100 \mathrm{~g}$ DWB) of juice, nonsignificant increase in color of juice, and highly significant decrease in reducing sugars $\%$ and titratable acidity of juice of juice extracted from sugar cane and sweet sorghum at different formula and clarification treatments. This result might be attributed to there was a positive relationship between Fe content and both of ash $\%$ and color of juice. These findings are in same line with results of [15].

Table 5. Correlations of minerals with physiochemical properties of juice.

\begin{tabular}{|c|c|c|c|c|c|}
\hline Correlations & $\mathrm{K}(\mathrm{mg} / \mathbf{1 0 0 g})$ & $\mathrm{Na}(\mathrm{mg} / \mathbf{1 0 0 g})$ & $\mathrm{Ca}(\mathrm{mg} / \mathbf{1 0 0 g})$ & Mg (mg/100g) & $\mathrm{Fe}(\mathrm{ppm})$ \\
\hline Moisture\% & $.832 * *$ & $.929 * *$ & $.924 * *$ & $.971 * *$ & $.860 * *$ \\
\hline Sucrose $\%$ & $.899 * *$ & $.933 * *$ & $.934 * *$ & $.958 * *$ & $.931 * *$ \\
\hline Reducing sugars\% & $-.911 * *$ & $-.964 * *$ & $-.954 * *$ & $-.986 * *$ & $-.914 * *$ \\
\hline Protein $\%$ & -0.483 & $-.519 *$ & $-.534 *$ & $-.612 *$ & -0.38 \\
\hline Lipid\% & $.699 * *$ & $.717 * *$ & $.678 * *$ & $.620 *$ & $.767 * *$ \\
\hline Ash\% & $.871 * *$ & $.843 * *$ & $.826 * *$ & $.743 * *$ & $.892 * *$ \\
\hline Titratable Acidity & $-.971 * *$ & $-.946 * *$ & $-.929 * *$ & $-.911 * *$ & $-.975 * *$ \\
\hline $\mathrm{TSS} \%$ & $.904 * *$ & $.957 * *$ & $.958 * *$ & $.989 * *$ & $.905 * *$ \\
\hline Color & 0.136 & 0.054 & 0.02 & -0.1 & 0.196 \\
\hline $\mathrm{pH}$ value & $.914 * *$ & $.961 * *$ & $.947 * *$ & $.979 * *$ & $.906 * *$ \\
\hline Purity $\%$ & $.696 * *$ & $.693 * *$ & $.733 * *$ & $.721 * *$ & $.725 * *$ \\
\hline
\end{tabular}




\begin{tabular}{|c|c|c|c|c|c|}
\hline Correlations & $\mathrm{K}(\mathrm{mg} / \mathbf{1 0 0 g})$ & $\mathrm{Na}(\mathrm{mg} / \mathbf{1 0 0 g})$ & Ca (mg/100g) & Mg (mg/100g) & $\mathrm{Fe}(\mathrm{ppm})$ \\
\hline $\mathrm{K}(\mathrm{mg} / 100 \mathrm{~g})$ & 1 & $.957 * *$ & $.963 * *$ & $.921 * *$ & $.968 * *$ \\
\hline $\mathrm{Na}(\mathrm{mg} / 100 \mathrm{~g})$ & $.957 * *$ & 1 & $.974 * *$ & $.971 * *$ & $.959 * *$ \\
\hline $\mathrm{Ca}(\mathrm{mg} / 100 \mathrm{~g})$ & $.963 * *$ & $.974 * *$ & 1 & $.967 * *$ & $.951 * *$ \\
\hline $\mathrm{Mg}(\mathrm{mg} / 100 \mathrm{~g})$ & $.921 * *$ & $.971^{* *}$ & $.967 * *$ & 1 & $.930 * *$ \\
\hline $\mathrm{Fe}(\mathrm{ppm})$ & $.968 * *$ & $.959 * *$ & $.951 * *$ & $.930 * *$ & 1 \\
\hline
\end{tabular}

** Correlation is significant at the 0.01 level (2-tailed).

* Correlation is significant at the 0.05 level (2-tailed).

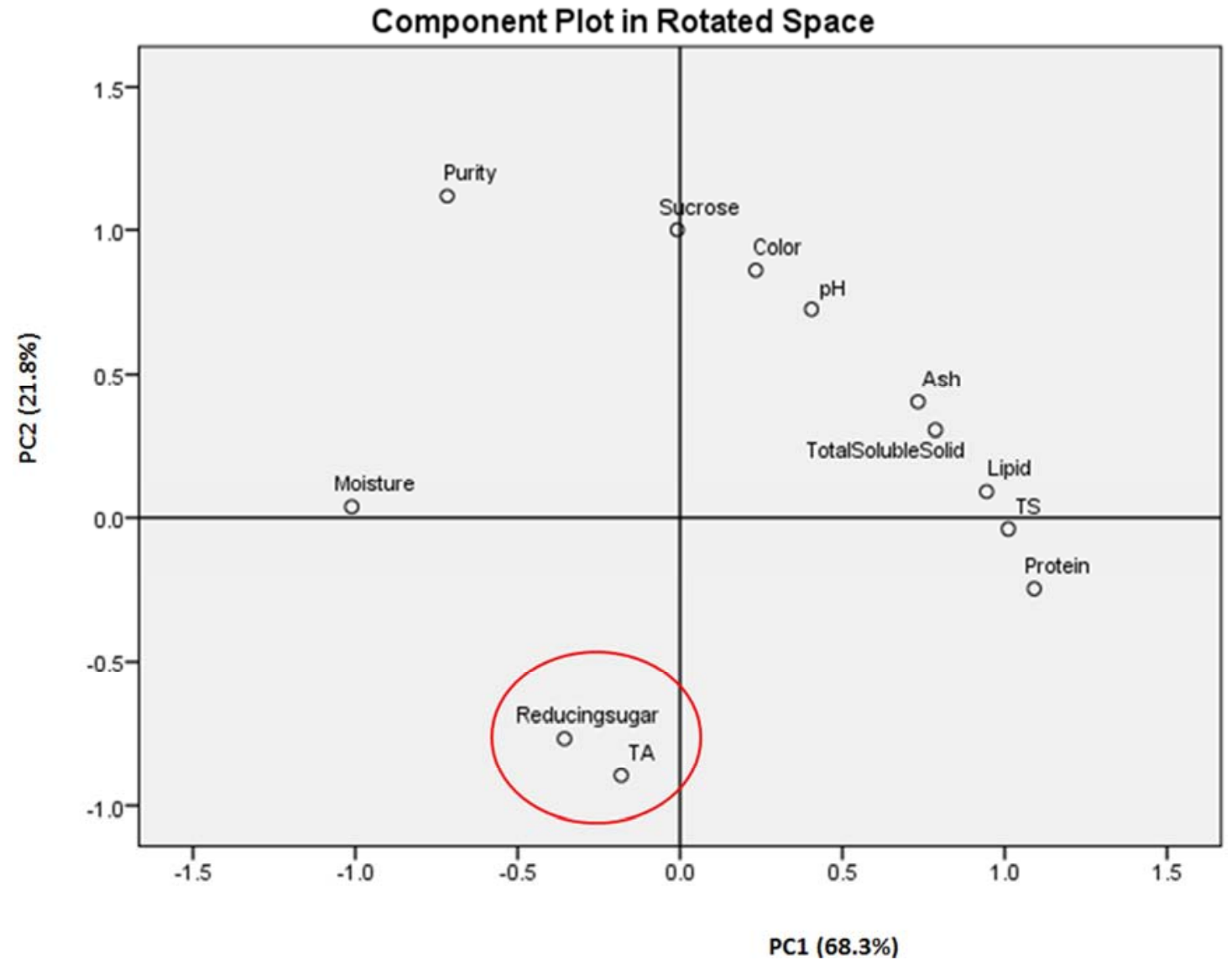

Figure 10. Principle component analysis for physiochemical properties of different juices.

\section{Conclusions}

From the present work, there were a great variations between the physicochemical parameters and sensory properties for formula of juice extracted from CJ and SJ and clarification treatments, not necessarily implying a problem of technological quality as fresh bever or raw material for syrup (black honey) production. It could be revealed from the data that use of formula $\left(\mathrm{A}_{2}\right)$ with clarification treatment $\left(\mathrm{B}_{2}\right)$ recorded the highest value of taste (22.70), flavor (23.17) and preference (23.80) and is advisable under the present work conditions.

\section{References}

[1] Akbulut M. and M. M. Özcan (2008): Some physical, chemical and rheological properties of sweet sorghum (Sorghum bicolor L. Monech) Pekmez (Molasses).. International Journal of Food Properties, 11: 79-91.
[2] AOAC (2007) International: Official Methods of Analysis of the Association of Official Analytical Chemists. Association of Official Analytical Chemists, Arlington, VA, USA.

[3] Chauhan O. P., Dheer Singh, S. M. Tyagi, and D. K. Balyan (2002): Studies on preservation of sugar cane juice. International Journal of Food Properties, 5 (1), 217-229.

[4] Cui, Y. and Y. Liang (2015): Sweet sorghum syrup as a renewable material for microbial lipid production. Biochemical Engineering Journal 93 (2015) 229-234.

[5] Eggleston, G. (2018): Positive Aspects of Cane Sugar and Sugarcane Derived Products in Food and Nutrition. Journal of Agriculture and Food Chemistry, vol. 66, n. 16, p. 4007-4012.

[6] Elmadfa, I. and Meyer, A. L. (2010): Importance of food composition data to nutrition and public health. European Journal of Clinical Nutrition, vol. 64, n. 3, p. S4-S7.

[7] Engo, N., Fuxman, A., González, C., Negri, L., Polenta, G., and Vaudagna, S. (2015): "Desarrollo sobre las exigencias sobre calidad e inocuidad de alimentos en el mundo, 2025". Buenos Aires. Argentina, pp. 1-290. (C. F. Moreno, et al. 2016). 
[8] García, H., Albarracín, L., Toscano, A., Santana, N., and Insuasty, O. (2007): "Guía tecnológica para el manejo integral del sistema productivo de caña panelera". (CORPOICA). Colombia, pp. 99 (C. F. Moreno, et al. (2016).

[9] Gomez, K. A. and A. A. Gomez (1984). Statistical Procedures of Agricultural Research (2nd ed.). John Willey and Sons, New York, pp: 680.

[10] Guerra, M., and Mujica, M. (2009): "Physical and chemical properties of granulated cane sugar "panelas". 30 (1): 1-9.

[11] Hatamipour, M. S., A. Almodares, M. Ahi, M. A. Gorji and Q. Jahanshah (2015): Cane Honey: Process, Quality and Harmlessness. International Journal of Engineering Research (online), Volume No. 5, Issue No. 7, pp: 589-593.

[12] ICUMSA (2011): Method book. International Commission for Uniform Methods of Sugar Analysis. Berlin, Germany: Bartens. 128p.

[13] Jeronimo, E. M. (2018): Produção de açúcar mascavo, rapadura e melado no âmbito da agricultura familiar e sua importância na alimentação humana. In: Magnoni Junior, L.; Stevens, D.; Purini, S. R. M.; Magnoni, M. G. M.; Vale, J. M. F.; Branco Junior, G. A.; Adorno Filho, E. F.; Da Silva, W. T. L. \& Figueiredo, W. S. (Eds.) (C. F. Polette, et al. 2019).

[14] Kappico, J., Suzuki, A., and Hongu, N. (2012): "Is Honey the Same as Sugar?". The University of Arizona. (2012). AZ 1577, EU, pp. 1-4.

[15] Kunitake M.; C. Ditchfield, C. Silva; R. Petrus (2014): Effect of pasteurization effects temoerature on stability of an acidified sugar cane juice beverage.. Ciênc. Agrotec., Lavras, v. 38, n. 6, p. 554-561. (C. F. Polette, et al. 2019).

[16] Li, Y.; Fang Yuan F. and Wang B. (2018): Changes in the sugar content of sweet sorghum stems under natural conditions during winter in saline soil of the Yellow River Delta. IOP Conf. Series: Earth and Environmental Science 113.

[17] Makori, E. M. (2013): The Potential of Sweet Sorghum [Sorghum Bicolor (L.) Moench] As A Bio- Resource for Syrup and Ethanol Production in Kenya. M.Sc. Thesis, Jomo Kenyatta University of Agriculture and Technology, Kenya.
[18] Mekdad, A. A. A. and A. M. A. El-Sherif (2016: The Effect of Nitrogen and Potassium Fertilizers on Yield and Quality of Sweet Sorghum Varieties under Arid Regions Conditions. Int. J. Curr. Microbiol. App. Sci 5 (11): 811-823.

[19] Moreno, W. F. Q.; E. G. Suárez; W. D. Q. Torres and M. C. Aguas (2016): Cane Honey: Process, Quality and Harmlessness. International Journal of Engineering Research Volume No. 5, Issue No. 7, pp: 589-593.

[20] Niemeyer A. N. and Vera S. (2008): "Soberanía alimentaria y seguridad alimentaria": XLVI Congresso da Sociedade Brasileira de Economia, administração e Sociologia Rural. Brasil, pp. 1-18. (C. F. Moreno, et al. 2016).

[21] Polette, C. M. V.; J. S. A. H. S. Bele and M. T. M. R. Marta; H. F. Spoto and M. V. Bernardi (2019): Physicochemical and sensorial characterization of commercial sugarcane syrups. Revista de Ciências Agrárias, 2019, 42 (3): 808-816.

[22] Rao, S. S.; J. V. Patil; D. Chandrasekara Reddy; B. S. Vijay Kumar; P. Srinivasa Rao and S. R. Gadakh (2013): Effect of Different Crushing Treatments on Sweet Sorghum Juice Extraction and Sugar Quality Traits in Different Seasons. Sugar Tech, 15 (3): 311-315.

[23] Ruiz -Matute, R. A. I.; a, A. C. Soria b; M. L. Sanz a, I. and Martı'nez-Castro (2010): Performance Evaluation of Sweet Sorghum Juice and Sugarcane Molasses for Ethanol Production Polish Journal of Chemical Technology, 17, 3, 1318.

[24] Silva, N. (2007): Manual de Métodos de Análise Microbiológica de Alimentos. São Paulo: Varela, 536p., (C. F. Moreno, et al. 2016).

[25] Turkmen, N., Sari, F., Poyrazoglu, E. S., Velioglu, Y. S., (2006): Effects of prolonged heating on antioxidant activity and color of honey. Food Chemistry 95, 653-657.

[26] Yusof, S.; Shian, L. S.; Osman, A. (2000): Changes in quality of sugarcane juice upon delayed extraction and storage. Food Chemistry. 68 (4): 395-401. 